\title{
Corrigendum: Genetic Background Influences the Propagation of Tau Pathology in Transgenic Rodent Models of Tauopathy
}

Tomas Smolek ${ }^{1,2}$, Veronika Cubinkova ${ }^{1,2}$, Veronika Brezovakova ${ }^{1}$, Bernadeta Valachova $^{2}$, Peter Szalay ${ }^{1,2}$, Norbert Zilka ${ }^{1,2}$ and Santosh Jadhav ${ }^{1,2 *}$

${ }^{1}$ Institute of Neuroimmunology, Slovak Academy of Sciences, Bratislava, Slovakia, ${ }^{2}$ Axon Neuroscience R\&D Services SE, Bratislava, Slovakia

Keywords: tauopathy, neurofibrillary tangles, microglia, genetic background, ramified

\section{A Corrigendum on}

OPEN ACCESS

Approved by:

Frontiers Editorial Office,

Frontiers Media SA, Switzerland

${ }^{*}$ Correspondence:

Santosh Jadhav

santosh.jadhav@savba.sk

Received: 28 January 2020

Accepted: 29 January 2020

Published: 18 February 2020

Citation:

Smolek T, Cubinkova $V$ Brezovakova $V$, Valachova $B$, Szalay $P$

Zilka N and Jadhav S (2020) Corrigendum: Genetic Background Influences the Propagation of Tau Pathology in Transgenic Rodent Models of Tauopathy.

Front. Aging Neurosci. 12:30 doi: 10.3389/fnagi.2020.00030
Genetic Background Influences the Propagation of Tau Pathology in Transgenic Rodent Models of Tauopathy

by Smolek, T., Cubinkova, V., Brezovakova, V., Valachova, B., Szalay, P., Zilka, N., et al. (2019). Front. Aging Neurosci. 11:343. doi: 10.3389/fnagi.2019.00343

There is an error in the Funding statement. The correct number for the first APVV grant is APVV-17-0642. The corrected statement appears below.

\section{FUNDING}

The work was supported by research grants APVV-17-0642, APVV-18-0515, VEGA 2/0181/17 VEGA 2/0135/18, and VEGA 2/0167/17.

The authors apologize for this error and state that this does not change the scientific conclusions of the article in any way. The original article has been updated.

Copyright (๑) 2020 Smolek, Cubinkova, Brezovakova, Valachova, Szalay, Zilka and Jadhav. This is an open-access article distributed under the terms of the Creative Commons Attribution License (CC BY). The use, distribution or reproduction in other forums is permitted, provided the original author(s) and the copyright owner(s) are credited and that the original publication in this journal is cited, in accordance with accepted academic practice. No use, distribution or reproduction is permitted which does not comply with these terms. 